\title{
ARVOSTELUJA
}

\section{Monikulttuuristen lääkärin vastaanottojen vuorovaikutuksesta}

Jenny PaAnANEN: Yhteisymmärryksen rakentaminen monikulttuurisilla lääkärin vastaanotoilla. Scripta Lingua Fennica Edita. Turun yliopiston julkaisuja C:465. 308 s.

Jenny Paananen tutkii väitöskirjassaan lääkärin ja potilaan vuorovaikutusta vastaanotoilla, joissa toinen osapuolista puhuu suomea ensikielenään ja toiselle suomi on toinen kieli. Metodisesti tutkimus ankkuroituu keskustelunanalyyttiseen tutkimustraditioon painottaen vuorovaikutuksen multimodaalista analyysia. Lääkäri-potilas-vuorovaikutusta on keskustelunanalyyttisesti tutkittu jo varsin laajasti niin Suomessa kuin muuallakin maailmassa, mutta Paanasen tutkimus tuo uuden näkökulman aiheeseen kohdistamalla huomion osapuolten epäsymmetriseen kielitaitoon ja sen vaikutuksiin vastaanoton vuorovaikutustilanteessa. Aihe on ajankohtainen ja yhteiskunnallisen keskustelun kohteena monissa Euroopan maissa: globaalin liikkuvuuden lisääntyminen, väestön ikääntyminen ja työvoiman tarve monimuotoistavat niin terveydenhuollon ammatti- kuin asiakaskuntaakin ja tuovat mukanaan kieli- ja kulttuurieroihin liittyviä haasteita. Työn johdannossa Paananen linkittää tutkimuksensa ansiokkaasti suomalaisen terveydenhuollon kontekstiin ja Suomessa käynnissä olevaan keskusteluun maahanmuuttajalääkäreistä ja -potilaista terveydenhuollon toimijoina.

Väitöstutkimuksen aineistona on 48 videoitua yleislääkärin vastaanottoa, joista 21:ssä lääkärin ensikieli on suomi ja 27:ssä suomi on lääkärin toinen kieli. Kaikilla vastaanotoilla kuitenkin puhutaan suomea toisena kielenä, sillä ensikielenään suomea puhuvilta lääkäreiltä on valittu tutkittavaksi vastaanottoja, joissa potilas on maahanmuuttaja(taustainen). Aineiston erityisenä ansiona onkin, että suomi ensikielenä $\left(\mathrm{S}_{1}\right)$-puhujia ja suomi toisena kielenä $\left(\mathrm{S}_{2}\right)$ - puhujia on molemmissa rooleissa, sekä lääkäreinä että potilaina. Kielellistä epäsymmetriaa tarkasteltaessa asetelma on usein sellainen, että ensikielinen puhuja on myös institutionaalisesti valta- tai asiantuntija-asemassa, jolloin toisen kielen puhujan rooliksi hahmottuu helposti aina jollain tavoin alisteinen institutionaalinen asema. Paanasen tutkimusasetelma purkaa tätä oletusta tarkastelemalla S2-puhujia myös (lääketieteellisessä) asiantuntija-asemassa.

Jenny Paanasen tutkimus on artikkeliväitöskirja, joka koostuu laajasta yhteenveto-osasta ja viidestä vertaisarvioidusta tutkimusartikkelista. Yksi artikkeleista on yhteisjulkaisu toisen kirjoittajan kanssa; tekijän oma osuus, joka on analyyttisesti merkittävämpi kuin toisen kirjoittajan osuus, on eritelty huolellisesti. Artikkeleista neljä on julkaistu suomeksi suomalaisissa tieteellisissä lehdissä ja viides, yhteisjulkaisu, englanniksi julkaisuluokitukseltaan korkeimman tason kansainvälisessä lehdessä (Journal of Pragmatics). Paanasen tutkimus on artikkelimuotoiseksi nykyväitöskirjaksi melko laaja; esimerkiksi Helsingin ja Jyväskylän yliopistot ohjeistavat artikkeliväitöskirjojen suosituslaajuudeksi 3-5 artikkelia ja Turun yliopisto vähintään neljä 
artikkelia, joista kolmen tulee olla joko julkaistuja tai julkaistuksi hyväksyttyjä. Paanasen kaikki viisi artikkelia ovat väitöskirjassa jo julkaistuina versiona. Paanasen tutkimus olisi ollut hyväksyttävissä väitöskirjaksi, vaikka siihen olisi sisällyttänyt vain neljä artikkelia, mutta tutkimuksen laajuus antaa ilman muuta kattavamman kuvan tarkasteltavasta ilmiöstä. Tutkimusartikkeleissa tarkastellaan eleiden käyttöä vastaanotoilla, lääkärien kysymyksiä ja niiden uudelleenmuotoiluja, lääkärien selityksiä, vuorovaikutusta tulkatuilla vastaanotoilla sekä päätöksentekoa ja potilaan osallisuutta päätöksiin.

Artikkeleista ensimmäinen tarkastelee eleiden merkitystä yhteisymmärryksen rakentamisessa. Artikkeli osoittaa kiinnostavalla tavalla, kuinka sekä lääkärit että potilaat hyödyntävät ikonisia ja deiktisiä eleitä varmistamassa yhteisen ymmärtämisen saavuttamista. Lääkärin vastaanotolla, jossa puheenaiheet ovat yleensä hyvin kehollisia - ruumiinosat, oireet, tapaturmat, hoidot - on luontevaa havainnollistaa vaikkapa kaatumisen kuvausta ikonisella eleellä tai varmistaa ruumiinosaa kuvaavan sanan ymmärtäminen osoittamalla kyseistä ruumiinosaa deiktisellä eleellä. Paananen analysoi eleitä eritoten keskusteluissa, joissa osapuolten yhteinen sanavarasto on varsin rajallinen. Eleillä paikataan sanavaraston puutteita, mutta Paananen osoittaa myös, kuinka eleet ovat perustavanlaatuinen osa inhimillistä vuorovaikutusta, resurssi, jolla voidaan tarkentaa, elävöittää ja painottaa sanottua sekä rakentaa yhteisyyttä. Artikkeliin valitut esimerkit, joissa lääkäri ja äiti selvittävät eleiden avulla lapsen silmätulehduksen oireita tai jossa vanhempi mies, hänen tyttärensä ja lääkäri selvittävät miehen sydänoireita, ovat erittäin kuvaavia ja jopa koskettavia; Paananen näyttää niiden avulla eleiden voiman yhteistyön rakennusaineena.

Väitöskirjan toinen artikkeli tarkastelee lääkärin esittämiä kysymyksiä ja niiden uudelleenmuotoiluja tilanteissa, joissa kysymykseen ei tule odotuksenmukaista vastausvuoroa. Kysymystä voi seurata lääkärin näkökulmasta joko vääränlainen vastaus, vastaus voi puuttua kokonaan tai potilas voi esittää korjausaloitteen. Paananen havaitsee, että lääkäri kyllä esittää kysymyksensä uudelleen, jos potilaan tuottama vastaus on hänen näkökulmastaan vääränlainen, mutta tätä niin sanottua kolmannen position korjausta (ks. Schegloff 1992) ei usein kuitenkaan tehdä avoimesti korjaavana toimintana. Potilaan kuvaus voidaan ottaa vastaan myönnytellen tai lääkäri voi esittää uudelleenmuotoillun kysymyksensä ikään kuin uutena, ensimmäisen position jatkokysymyksenä. Lääkärit siis pyrkivät välttämään väärinymmärrysten tuomista keskustelun pintaan. Lääkärit muokkaavat kysymyksiään usein erilaisilla prosodisilla keinoilla (painotus, hidastus jne.), lisäämällä eleitä tai muokkaamalla kysymyksen rakennetta. Huomionarvoinen on Paanasen havainto siitä, että keskimäärin (ensikieleltään suomenkieliset) lääkärit lähtevät siitä oletuksesta, että potilas ei ymmärrä heidän kysymystään sellaisissakin tilanteissa, joissa he itse eivät tunnista potilaan vastausta. Kielellinen epäsymmetria on siis ikään kuin pinnanalaisesti jatkuvasti läsnä, ja vuorovaikutuksen ongelmat tulkitaan herkästi suhteessa osapuolten kielellisiin asemiin ensikielisinä tai kakkoskielisinä suomenpuhujina.

Väitöskirjan kolmannessa artikkelissa tarkastelun kohteena ovat lääkärin selitykset lääketieteellisistä termeistä tai muista asiantuntijailmauksista. Tämä artikkeli on lähtökohdiltaan vahvimmin lingvistisesti painottunut; Paananen kartoittaa lääkärien käyttämiä selityskeinoja erilaisten semanttisten piirteiden avulla ja luokittelee selityksiä niissä esiintyvien kieliopillisten rakenteiden mukaan. Myös tässä artikkelissa Paananen esittää huomioita eleistä, mutta eleiden osuus tarkasteltavassa selittämistoiminnassa jää melko lailla maininnan tasolle. Artikkeli tuo esiin kiinnostavaa tietoa lääkärien selitysten rakentumisesta ja Paananen peilaa tätä tietoa ansiokkaasti aiempien tutkimusten tuloksiin selityksistä muissa ympäristöissä (esim. perinnöllisyysneuvonnassa tai pedagogisissa tilanteissa). Väitöskirjan kokonaisuudessa artikkeli 
kuitenkin tuntuu hieman erottuvan muista pikemminkin kieliopillisen kuin vuorovaikutuksellisen lähtökohtansa ansiosta. Paananen esimerkiksi mainitsee, että tarkasteltavana olevat selitykset voivat olla joko lääkärien oma-aloitteisia selityksiä tai reaktioita potilaiden kysymyksiin tai väärinymmärryksiin. Nämä selitysten erilaiset sekventiaaliset asemat eivät kuitenkaan tule analyysissa esiin; vuorovaikutuksellisesta näkökulmasta olisi ollut kiinnostavaa tietää, onko sekventiaalisilla asemilla vaikutusta selitysten rakentumiseen.

Väitöskirjan neljäs artikkeli on yhteisjulkaisu toisen kirjoittajan, Ali Reza Majlesin kanssa. Artikkelissa tarkastellaan lääkärin vastaanottoja, joissa on mukana tulkki. Paanasen aineisto on ainutlaatuisen rikas sikäli, että se sisältää käytännössä kaikki vaihtoehdot tilanteista, joissa suomi ei ole jonkun osapuolen ensikieli: suomea toisena kielenä puhuvien lääkärien ja potilaiden lisäksi on saatu tallennettua myös suomeksi tulkattuja vastaanottoja, joissa potilas puhuu ensikieltään. Tulkin käyttäminen antaa lääkärille ja potilaalle mahdollisuuden käyttää vapaammin oman kielensä resursseja, mutta saattaa toisaalta aiheuttaa muita vuorovaikutukseen liittyviä ongelmia. Paananen ja Majlesi käyvät ansiokkaasti läpi tulkkaukseen liittyviä aiemman tutkimuksen havaintoja, joista monet liittyvät kolmenvälisen osallistujakehikon ongelmiin. Periaatteessa keskustelun pääosapuolet ovat lääkäri ja potilas, ja tulkki toimii välittäjänä heidän keskustelussaan, mutta tutkimukset osoittavat, että toisinaan tulkin osuus voi nousta vuorovaikutuksessa jopa niin kohosteiseksi, että lääkäri alkaa käydä keskustelua pikemminkin tulkin kuin potilaan kanssa.

Ongelmallisuutta korostavan lähestymistavan sijaan Paananen ja Majlesi valitsevat toisen lähtökohdan: heidän tutkimuksensa tarkastelee tulkattuja lääkärin vastaanottoja suhteessa potilaslähtöisyyteen, joka on yksi nykyisen länsimaisen terveydenhuollon kantavista perusperiaatteista. Ratkaisu on onnistunut ja rajaa tutkimusta tuoreella ja kiinnostavalla tavalla. Paananen ja Majlesi osoittavat, kuinka erilaisilla tulkkausvalinnoilla pystytään tuomaan esiin potilaan näkökulmaa. Erityisen kiinnostava on heidän analyysinsa eleistä tulkatuilla vastaanotoilla: eleiden avulla tulkit pystyvät rakentamaan yhteisyyttä ja avaamaan potilaalle ja lääkärille pääsyä niihin vuoroihin, joihin heillä ei ole kielellistä pääsyä.

Väitöskirjan viimeinen artikkeli käsittelee päätöksentekoa, joka on ollut laajan kiinnostuksen kohteena lääkäri-potilas-vuorovaikutuksen tutkimuksessa viime vuosina. Paananen osallistuu artikkelillaan tähän keskusteluun peilaten aiemman tutkimuksen havaintoja oman aineistonsa kielellisesti epäsymmetrisiin vastaanottotilanteisiin. Tarkemman analyysin kohteeksi on otettu päätöksentekojakson aloittavat vuorot eli vuorot, joilla päätökset tuodaan keskusteltaviksi. Rajaus on onnistunut, koska se osoittautuu keinoksi päästä jälleen kiinni potilaslähtöisyyteen - joka on olennainen käsite suomalaisessa terveydenhuollossa mutta ilman konkretiaa jää helposti varsin yleisluonteiselle tasolle. Paananen suhteuttaa kartoittamansa päätösaloitetyypit jatkumolle potilaskeskeisistä kohti lääkärikeskeisempiä ilmauksia. Paananen nostaa myös aiheellisesti esiin kysymyksen siitä, mikä on tietynmuotoisia päätösaloitteiden ja potilaan huomioimisen välinen suhde. Tietyt päätösaloitetyypit voidaan määritellä deonttisin ja episteemisin perustein lääkärikeskeisiksi, mutta näiden ilmausten käyttö ei suinkaan automaattisesti tarkoita, että potilasta ja hänen näkemyksiään ei otettaisi huomioon päätöksenteossa.

Tämä osatutkimus on ainoa väitöskirjan artikkeleista, jossa jo tutkimuskysymyksissä lähdetään liikkeelle kieliryhmiä vertailevalla otteella; yksi tutkimuksen tavoitteista on selvittää, onko suomea äidinkielenään puhuvien ja suomea toisena kielenä puhuvien lääkäreiden käyttämissä päätösaloitteissa eroja. Tuloksista selviää, että ryhmien välillä on eroja: ulkomaalaistaustaiset lääkärit käyttävät enemmän velvoittavia päätösaloitteita ("no täytyy ottaa röntgenkuva"), kun taas suomea ensikielenään puhuvat lääkärit käyttävät enemmän tarjous- ja ehdotusmuotoisia 
aloitteita ("ihan varmuudeks otettais tämmönen pissanäyte myös"). Tulos on merkittävä, koska vuorovaikutus lääkärin ja potilaan välillä vaikuttaa olennaisesti potilaiden kokemuksiin lääkärikäynnin onnistumisesta ja varsin pienetkin kielelliset valinnat voivat vaikuttaa tulkintaan siitä, miten lääkäri kohtaa potilaan. On kaikkien kannalta epäonnista, jos lääkäreiden kielitaidon rajallisuus aiheuttaa sen, että potilaat kokevat lääkärin töykeäksi tai autoritaariseksi. Paanasen tutkimustulokset ovat suoraan hyödynnettävissä lääkärien kielikoulutuksessa ja osoittavat empiriaan pohjaavan keskustelunanalyyttisen metodin vahvuuden. On aivan eri asia kyetä esittämään konkreettisia kielellisiä malleja toimivista käytänteistä kuin antaa ohjeeksi "keskustele päätöksestä potilaslähtöisellä tavalla". Paanasen tulokset antavat kielenopettajalle välineitä opettaa ammattikieltä kohdennetummin. Esimerkiksi Paanasen havainto, että suomea toisena kielenä puhuvat lääkärit eivät juurikaan käytä päätösaloitteissaan konditionaalia (toisin kuin suomea ensikielenään puhuvat), tarjoaa ilmeisen ja konkreettisen opetuskohteen lääkärien kielikoulutukseen. Paananen ounastelee konditionaalin puutteen johtuvan suomen kielen taivutuksen oppimisen vaikeudesta, mutta yhtä hyvin syynä voi olla se, että lääkäri ei tiedä konditionaalimuodon olevan sopiva tapa päätöksen esittämiseen (mitä vastaava muoto ei muissa kielissä välttämättä ole). Artikkelin tulokset ovat ehdottoman tärkeitä, ja on toivottavaa, että Paananen levittää tätä arvokasta tietoa mahdollisimman laajasti myös tiedeyhteisön ulkopuolelle, erityisesti ammattikielen opetuksen toimijoille.

Väitöskirjan yhteenvedossa Paananen sijoittaa tutkimuksensa sekä yhteiskunnalliseen että tieteelliseen kontekstiin. Yhteenvedossa Paananen käy läpi artikkeliensa taustat, aineistot, menetelmät ja pääasialliset tulokset. Jos väitöskirjan lukee kokonaisuutena, toisteisuutta on väistämättä paljon, mutta tämä ei toki ole vain Paanasen väitöskirjan ongelma, vaan juontuu artikkeliväitöskirjan rakenteesta: kaikissa artikkeleissa esitetään väistämättä samaa taustatietoa, ja artikkeleiden tulokset esitetään artikkelien lisäksi myös yhteenvedossa. Paanasen väitöskirjan vahvuutena on Paanasen kautta linjan käymä keskustelu tulosten sovellettavuudesta; tutkimus on toteutettu tieteellisen kurinalaisesti ja Paananen hallitsee oivallisesti käyttämänsä metodin, mutta hän pystyy myös varsin kypsästi hahmottamaan tieteellisten tulostensa relevanssia ulkomaailman näkökulmasta. Esimerkiksi yhteenvedon pohdinta-jaksossa Paananen esittää arvokkaita ja tärkeitä näkemyksiä siitä, kuinka potilaskeskeisyys ja lääkärivetoisuus eivät välttämättä ole ristiriidassa keskenään tai siitä, mikä osuus kielellä on terveyspalvelujen järjestämisen, osallisuuden ja saavutettavuuden näkökulmasta.

Kaiken kaikkiaan Jenny Paanasen väitöskirja on perusteellinen, monipuolinen ja metodisesti hallittu kokonaisuus. Se tuo uutta tutkimustietoa liittyen niin kielelliseen epäsymmetriaan, lääkäri-potilas-vuorovaikutukseen kuin multimodaalisuuteen yhteisymmärtämisen rakennusaineena. Tutkimuksen teemat ovat erittäin ajankohtaisia kansainvälisestikin.

SAlla Kurhila

salla.kurhila@helsinki.fi

Suomalais-ugrilainen ja pohjoismainen osasto

PL 3, 00014 Helsingin yliopisto

\section{Lähteet}

Schegloff, E. 1992: Repair after next turn. The last structurally provided defense of intersubjectivity in conversation. American Journal of Sociology 97, 1295-1345. 